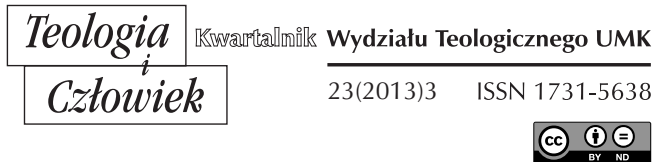

KS. ROMANO PENNA*

RZYM

\title{
WIARA I NAWRÓCENIE W ŻYCIU I MYŚLI ŚW. PAWŁA
}

DOI: http://dx.doi.org/10.12775/TiCz.2013.035

Wiara i nawrócenie są dwoma biegunami, które nakładają się na siebie jedynie częściowo. Jednakże odnośna semantyka jest inna. Gdy w liście apostolskim Porta fidei Benedykt XVI pisze, że

Rok Wiary jest zaproszeniem do autentycznego i nowego nawrócenia się do Pana, jedynego Zbawiciela świata", dokonuje implicite rozróżnienia pomiędzy dwoma faktorami: przywołując konieczność nowego życia, tekst w dalszej części stwierdza, że „dzięki wierze, to nowe życie kształtuje całą ludzką egzystencję, opierając się na radykalnej nowości zmartwychwstania. $\mathrm{W}$ takiej mierze, $\mathrm{w}$ jakiej człowiek dobrowolnie okazuje gotowość, jego myśli, uczucia, mentalność i zachowania powoli są oczyszczane i przekształcane $\mathrm{w}$ procesie, który w tym życiu nigdy w pełni się nie kończy. Wiara, która dziata przez mitość $($ Ga 5,6) staje się nowym kryterium myślenia i działania, które przemienia całe życie człowieka (por. Rz 12,2; Kol 3,9-10; Ef 4,20-29; 2 Kor 5, 17) (n. 6).

" Ks. prof. dr hab. Romano Penna - profesor i wykładowca Nowego Testamentu w Papieskim Uniwersytecie na Lateranie; visiting professor na Papieskim Uniwersytecie Gregoriańskim w Rzymie, Papieskim Instytucie Biblijnym w Rzymie oraz w Papieskim Instytucie Biblijnym w Jerozolimie; specjalista od nauczania św. Pawła. Apostoła. 
Istotnie, sumarycznie rzecz ujmując, podczas gdy idea nawrócenia sytuuje się $\mathrm{w}$ obszarze zobowiązania moralnego, wiara znajduje się na poziomie całkowicie przed-moralnym. Należy jednak niezwłocznie dokonać tutaj pewnego uściślenia terminologicznego.

\section{WYJAŚNIENIE TERMINÓW}

Termin „nawrócenie” (po włosku conversione - przyp. tłum.) jest latynizmem (od con-versio, dosłownie: „zmiana kierunku”, „obrócenie / się/", „obrót", „zmiana”) i oddaje jedynie w sposób przybliżony greckie słowo metanoia, które dosłownie znaczy: „zmiana mentalności; przekroczenie własnego sposobu (noûs) myślenia". W autentycznych listach Pawłowych termin ten występuje zaledwie trzy razy ${ }^{1}$. Jeszcze bardziej znaczące jest użycie czasownika „nawracać się” / metanoê̂n / „zmieniać myśl”, który - w odróżnieniu od rzeczownika - wyraża lepiej aktywne i rzeczywiste zobowiązanie człowieka; w listach Pawłowych odnajdujemy go zaledwie jeden raz (w 2 Kor 12,21) $)^{2}$. Jest jasne, że ta koncepcja nie ma dla św. Pawła większego znaczenia ${ }^{3}$.

W przeciwieństwie do tego, termin „wiara” (fede), będący także (w języku włoskim - przyp. tłum.) latynizmem (od fides, tłumaczenie greckiego pistis), podczas gdy w Ewangeliach i w Dziejach Apostolskich spotykany jest 39 razy, w autentycznych listach Pawłowych jest udokumentowany aż 92 razy. Analogicznie słowo „wierzyć" (włoskie credere; po grecku pisteùein) został użyty przez Pawła 42 razy (wobec 34 razy u synoptyków oraz aż 99 razy tylko w samej Ewangelii św. Jana, która

${ }^{1}$ Por. Rz 2,4; 2 Kor 7,9-10 (także: 2 Tm 2,25). Natomiast w Ewangeliach (tylko synoptycznych) znajduje się 8 razy (do których należy dodać 6 razy w Łukaszowych Dziejach Apostolskich).

${ }^{2}$ Tymczasem czasownik ten jest obecny aż 16 razy w Ewangeliach (również jedynie u synoptyków) oraz 5 razy w Dziejach Apostolskich. Warto zaznaczyć, że najlepszego jego tłumaczenia dokonał Luter, który w nawiązaniu do Mt 4,17 (greckie: metanoeîte; Wulgata: paenitentiam agite; CEI: convertitevi) tłumaczył dosłownie po łacinie: transmentamini, co znaczy: „pójdźcie poza / przekroczcie/ waszą mentalność”(w pierwszej spośród 95 jego Tez)!

${ }^{3}$ Por. R. Penna, Pentimento e conversione nelle lettere di san Paolo: la loro scarsa rilevanza soteriologica confrontata con lo sfondo relogioso, w: tenże, Vangelo e inculturazione. Studi sul rapporto tra rivelazione e cultura nel Nuovo Testamento, Cinisello Balsamo 2001, s. 536-580. 
z kolei nie zna słownictwa pochodzącego od metánoia). Również w tym przypadku jest jasne, że odnośny czasownik, bardziej niż rzeczownik, wyraża przede wszystkim efektywne i osobiste działanie związane $\mathrm{z}$ wiarą człowieka, który dokładnie $\mathrm{z}$ tego powodu jest określany jako wierzacy.

Czasownik "credere/pisteùein” (wierzyć), z racji swoich korzeni etymologicznych ${ }^{4}$, oznacza właśnie „posiadać zaufanie (wobec kogoś), ufać, powierzać się, przyznawać rację, dawać wiarę, utrzymywać/uważać, wierzyć, być przekonanym/nakłonionym (do czegoś)" i - rozszerzając to znaczenie - „być przekonanym (o czymś), być pewnym (czegoś)”. Pierwszeństwo dane czasownikowi - w stosunku do rzeczownika - w Nowym Testamencie wynika $\mathrm{z}$ dwóch powodów: pierwszy związany jest $\mathrm{z}$ większą konkretnością semantyczną czasownika jako takiego, zważywszy, że wyraża on bardziej jakiś akt działania, niż jego rodzaj, bardziej dynamikę działania, niż jego jakość; drugi powód wynika z faktu, iż czasownik łączy się z wyraźną wielością konstrukcji (językowych), z których każda posiada inny odcień znaczeniowy mogący wyrazić znaczne bogactwo semantyczne $e^{5}$.

Może mieć tutaj znaczenie fakt, że imiesłowowi czasu teraźniejszego "wierzący”, który dotyczy stałego i ciągłego stanu tego, kto posiada wiarę, nie odpowiada jakiś analogiczny i leksykalnie niemożliwy termin „nawracający (się)”, mogący być zastąpiony przez imiesłów czasu przeszłego „nawrócony”. Jest to uzasadnione tym, że tak zwane nawrócenie następuje $\mathrm{w}$ mniej lub bardziej precyzyjnym momencie, podczas gdy wiara dotyczy całego życia. Stąd można powiedzieć, że nawrócenie jedynie otwiera drzwi do wiary. W każdym przypadku jedno nie dokonuje się bez drugiego. Czy też lepiej to wyrażając: podczas gdy możliwe jest pojmowanie nawrócenia jako przemiany czysto moralnej, która ma wymiar wewnątrz ludzki, to specyfika wiary chrześcijańskiej umieszcza człowieka na poziomie osobowej relacji z Bogiem i z Jezusem Chrystusem. Powyższa różnica jest wyraźnie widoczna w biografii św. Pawła.

${ }^{4}$ Etymologicznie pochodzi od peítho/peithomai, „przekonywać / przekonać / przekonać się": coś, co może się zdarzyć albo dzięki rozumowaniu, albo dzięki modlitwie, albo przy użyciu siły, albo pieniędzy.

${ }^{5}$ Por. R. Penna, Le costruzioni del verbo pisteùein nel Nuovo Testamento, w: A. Passoni Dell'Acqua (red.), Il vostro frutto rimanga (Gv 16,16). Miscellanea per il LXX compleanno di Giuseppe Ghiberti, Supplementi alla "Rivista Biblica" 46, Bologna 2005, s. 219-229. 


\section{RELACJA "NAWRÓCENIE - WIARA" W OSOBISTYM PRZYPADKU PAWŁA}

Należy uznać, że opowiadania o nawróceniu są w starożytności bardzo rzadkie. W praktyce, według mojej wiedzy, sprowadzają się do trzech i każdy z nich reprezentuje - różniącą się od innych - egzystencjalną przemianę: Polemon z Aten (koniec IV wieku przed Chr.), Izates z Adiabeny (epoka klaudyjska, połowa I wieku po Chr.) i Paweł z Tarsu (początek lat czterdziestych I wieku) ${ }^{6}$. Każdy z tych trzech przypadków przedstawia zróżnicowaną typologię. W efekcie, nawrócenie może się dokonać na trzy różne sposoby. Pierwszy polega na przejściu etycznym od życia marnotrawnego do życia bardzo surowego, co dokonuje się wewnątrz systemu wartości charakteryzującego globalnie daną społeczność. Z tego punktu widzenia, wydaje mi się, iż można powiedzieć, że przypadek Polemona z Aten został zaadaptowany - być może nieodwracalnie - także przez tradycję chrześcijańską dla wyrażenia całej serii tak zwanych nawróceń mających miejsce wewnątrz samej societas christiana, i uważanych (chodzi o nawrócenia, a nie o chrzest!) za początek życia w świętości; przykładów można podać bardzo wiele. Drugi typ, którego wzorem jest przypadek Izatesa, króla Adiabeny (region na pograniczu Turcji, Iraku i Syrii) polega na prawdziwej zmianie religii, przede wszystkim w sensie przejścia od pogaństwa do religii objawionej i monoteistycznej, jaką jest judaizm. Pomijając jakiekolwiek kalkulacje polityczne, które mogłyby stać u podstaw tej decyzji, typologia ta powinna także wyrażać przechodzenie wszystkich pogan na chrześcijaństwo w sensie przyjmowania wartości religijnych całkowicie przeciwnych tym ze stanu początkowego owej drogi: zarówno na poziomie wiary, jak i etyki. Najzwyklejsza tego świadomość prowadzi do odkrycia istotnych cech własnej, nowej tożsamości.

Trzecia typologia jest reprezentowana właśnie przez Pawła z Tarsu i jest we wszystkim oryginalna, gdyż pociąga za sobą współistnienie antynomiczne pomiędzy ciągłością i nieciągłością w relacji do poprzedniego statusu religijnego. Naświetla ona wyraźnie fundamentalny fakt nowości - w stosunku do dwóch pozostałych typologii - polegającej na tym, iż nawrócić się oznacza przylgnąć nie do jakiejś doktryny czy systemu reli-

${ }^{6}$ Szerzej zob. R. Penna, Tre tipologie di conversione raccontate nell'atichità: Polemone di atene, Izate dell' Adiabene, Paolo di Tarso, w: tenże, Vangelo e inculturazione, dz. cyt., s. 275-296. 
gijnego, lecz do pewnej osoby żywej i dającej wolność, jak Jezus Chrystus, zdolnej do skierowania $\mathrm{w}$ nową stronę nie tylko ludzkich sił, którymi się dysponuje, lecz także i poprzednich, własnych wartości religijnych.

Nie zatrzymując się nad kwestiami powszechnie znanymi, przypomnijmy, iż świadectw na temat św. Pawła jest kilka, i w części pochodzą one - co niewątpliwie przemawia na ich korzyść - spod jego pióra, a ponadto $\mathrm{z}$ odnośnej relacji sporządzonej przez Łukasza $\mathrm{w}$ Dziejach Apostolskich. Wynika z nich - najogólniej rzecz ujmując - że tylko ten drugi ofiaruje nam opowiadanie, zresztą powtórzone (por. Dz 9,1-19; 22,5-16; 26,9-18), dotyczące spotkania, które było dla Pawła decydujące. Natomiast sam zainteresowany zadowala się krótkimi wzmiankami, które jednak od razu objawiają w tym wydarzeniu egzystencjalną zdolność decyzji: Rz 1,5 („,Przez Niego [Jezusa Chrystusa] otrzymaliśmy łaskę i urząd apostolski, aby ku chwale Jego imienia pozyskiwać wszystkich pogan dla posłuszeństwa wierze.”); 1 Kor 9,1 („Czy nie widziałem Jezusa, Pana naszego?”); 1 Kor 15,8 („W końcu, już po wszystkich, ukazał się także i mnie jako poronionemu płodowi”); 2 Kor 4,6 („Bóg, Ten, który nakazał ciemnościom, by zajaśniały światłem [por. Rdz 1,3], zabłysnął w naszych sercach, by olśnić nas jasnością poznania chwały Bożej na obliczu Chrystusa”); Ga 1,15-16 („Gdy jednak spodobało się Temu, który wybrał mnie jeszcze $\mathrm{w}$ łonie matki mojej i powołał łaską swoją, aby objawić Syna swego we mnie, bym Ewangelię o Nim głosił poganom, natychmiast, nie radząc się ciała i krwi ani nie udając się do Jerozolimy, do tych, którzy apostołami stali się pierwej niż ja, skierowałem się do Arabii, a później znowu wróciłem do Damaszku”); Flp 3,4b-9 („Jeśli ktoś inny mniema, że może ufność złożyć w ciele, to ja tym bardziej: obrzezany w ósmym dniu, z rodu Izraela, z pokolenia Beniamina, Hebrajczyk z Hebrajczyków, w stosunku do Prawa - faryzeusz, co do gorliwości - prześladowca Kościoła, co do sprawiedliwości legalnej - stałem się bez zarzutu. Ale to wszystko, co było dla mnie zyskiem, ze względu na Chrystusa uznałem za stratę. I owszem, nawet wszystko uznaje za stratę ze względu na najwyższą wartość poznania Jezusa Chrystusa, Pana mojego. Dla Niego wyzułem się ze wszystkiego i uznaję to za śmieci, bylebym pozyskał Chrystusa i znalazł się w Nim - nie mając mojej sprawiedliwości, pochodzącej z Prawa, lecz Bożą sprawiedliwość, otrzymaną przez wiarę w Chrystusa, sprawiedliwość pochodzącą od Boga, opartą na wierze").

Pierwsze, zaskakujące ustalenie, które należy poczynić w odniesieniu do tych tekstów, to stwierdzenie, iż Paweł, w tym, co go dotyczy, nie używa nigdy słownictwa pochodzącego od terminu „nawrócenie”! 
Raczej odnotowuje za każdym razem własne doświadczenie przy użyciu wzniosłych idei łaski, wizji, ukazania, oświecenia, powołania, objawienia, zysku i wiary. W takim sposobie wyrażania się bez wątpienia ważną rolę odgrywa judaistyczny rys jego osobowości, ponieważ używa on terminologii „nawrócenia” jedynie w stosunku do „nawróconych” pogan (por. 1 Tes 1,9; Ga 4,9). Rzeczywiście, o Żydzie, który przylgnął do Jezusa, nie można powiedzieć, że się nawrócił, lecz że został „ponownie wszczepiony (włączony)" (Rz 11,24)7.

Poza tym, w tekstach, które zawierają jego świadectwo zawarty jest płomienny zapał, ukazujący jak gorące, i wyciskające piętno, i wstrząsające było opisane spotkanie. Tak, gdyż dla Pawła najwyraźniej było to niezwykłe spotkanie: spotkanie nie tylko z prostotą jakiegoś filozofa, którego ma się być następcą (jak w przypadku rozpustnego Polemona wobec posiadającego surowe obyczaje Ksenokratesa, kierownika Akademii Platońskiej w Atenach), i nawet nie z jakimś pośrednikiem w przyjęciu nowego prawa religijnego (jak to było w przypadku Żydów Ananiasza i Eleazara w stosunku do poganina Izatesa). Saul z Tarsu, jeśli można tak rzec, „zderzył się” z Osobą, która stała się całym sensem jego życia, aż po niebywałe wyznanie: „Teraz już nie ja żyję, lecz żyje we mnie Chrystus” (Ga 2,20)! Rzeczywiście, osoba Jezusa, spotkana na drodze do Damasz$\mathrm{ku}$, posiada cechy zupełnie oryginalne i nieporównywalne z nikim: Jego tożsamość jest doskonale pojmowalna wewnątrz szczególnego, idealnego świata, jakim jest świat judaizmu (ze swoim monoteizmem i nadziejami mesjańskimi, i ze swoją koncepcją wiary, grzechu, odkupienia itd.) i jakim jest świat specyficznie chrześcijański (z nowymi elementami wyrażanymi poprzez krzyż i zmartwychwstanie Jezusa). Ponadto Paweł spotyka Osobę, która jest już wpisana w historię i przemieniona chwałą Bożą (por. 2 Kor 4,6; Rz 8,34). Co więcej, należy doprecyzować, iż wydarzenie spod Damaszku nie jest możliwe do wyjaśnienia bez wzięcia pod uwagę wcześniejszej znajomości Chrystusa ze strony Pawła dzięki świadectwu pierwszych wspólnot chrześcijańskich (zresztą prześladowanych). Stąd doświadczenie ukazania się Chrystusa Pawłowi nie może być w sposób odpowiedni zrozumiane w perspektywie ujęcia czysto psychologicznego czy też jedynie socjologicznego, które bardzo redukowałyby to wyda-

${ }^{7}$ Zresztą, znana jest deklaracja Naczelnego Rabina Rzymu Eugenio Zolliego, który - otrzymawszy chrzest pod koniec drugiej wojny światowej - mawiał: „Ja nie jestem kimś nawróconym, lecz kimś, kto przybył". 
rzenie w jego całościowym ujęciu ${ }^{8}$. Nie byłoby również wystarczające przyjęcie szlachetnej kategorii powołania prorockiego, która - jeśli nawet można by tutaj odnaleźć dobre porównania w niektórych miejscach Starego Testamentu (przede wszystkim w Jr 1,5; Iz 49,1) - pomniejszałaby znaczenie braku ciągłości z przyszłym nauczaniem Apostoła, zupełnie zrywającym z dotychczasową jego postawą, zwłaszcza w odniesieniu do Prawa Mojżeszowego, w której to kwestii nie odnajdujemy żadnych możliwych odniesień.

Co więcej, jak ukazano w niektórych dobrych monografiach ${ }^{9}$, chrystofanię, której Paweł doświadczył na drodze do Damaszku, można wyjaśnić na tle Ez 1, gdzie wizja rydwanu (merkavàh) z czterema istotami żyjącymi jest tłumaczona jako wizja chwały Pana znajdującego się tam pod owymi tajemniczymi wyobrażeniami ludzkimi (por. Ez 1,26-28; 8,2). Ta oryginalna antropomorficzna wizja Boga i Jego chwały miała potem swoją szczęśliwą historię w literaturze judaistycznej, zwłaszcza w Księdze Daniela i w tradycji Henochickiej ${ }^{10}$. Także wzmianki u św. Pawła dotyczące wydarzenia spod Damaszku można wytłumaczyć na podstawie tego modelu interpretacyjnego, tym bardziej jeśli weźmiemy pod uwagę ważkość koncepcji "chwały” (doxa) w listach Apostoła w odniesieniu do Jezusa i Jego bycia Panem: zarówno w kontekście chrystologicznym (por. 1 Kor 2,8: „Pan chwały”; 2 Kor 4,4: „Ewangelia chwały Chrystusa"), w odniesieniu do aktualnego życia chrześcijan (por. 2 Kor 3,18: "stajemy się przemienieni chwałą w chwale”), jak i na etapie eschatologicznym (por. Flp 3,21: „abyśmy byli przekształceni na podobieństwo Jego ciała chwalebnego"). Słuszna jest przeto konkluzja, że chrystofania spod Damaszku stanowi dla Pawła podstawę prawdziwej i właściwej

8 Status questionis w bibliografii można znaleźć w: L. W. Hurtado, Convert, apostate or apostle to the nations: The "conversion" of Paul in recent scholarship, "Studies in Religion/Sciences Religieuses" 22(1993), s. 273-284; por także: G. Theissen, Psychologische Aspekte paulinischer Theologie, FRLANT 131, Vandenhoeck, Göttingen 1983, szczególnie s. 181-268; M. Reichardt, Psychologische Erklärung der paulinischen Damaskusvision?, SBB 42, Katholisches Bibelwerk, Stuttgart 1999.

${ }^{9}$ Zob. przede wszystkim: C. C. Newman, Paul's Glory-Christology. Tradition and Rhetoric, NT Suppl. 69, Brill, Leiden 1992.

${ }^{10}$ Por. L. H. Hurtado, One God. One Lord. Early Christian Devotion and Ancient Jewish Monotheism, SCM Press, Philadelphia 1988. Należy ponadto zauważyć, że - aby uniknąć potwierdzenia jakiejś bezpośredniej wizji Boga - targumy Księgi Wyjścia 24,10 („Ujrzeli Boga Izraela”) tłumaczą albo: „Ujrzeli chwałę Boga Izraela” (Tg Ps-Jon), albo „Ujrzeli chwałę Shekinah Yhwh" (tg N). 
chrystologii chwały, tzn. zrozumienia Chrystusa, zarówno w kontekście Jego własnej chwały, jak i w sensie darowania nowego oblicza chwały samego Boga.

Natomiast u podstaw relacji Łukaszowej tego wydarzenia stoją inne cele ${ }^{11}$. Już potrójne powtórzenie opowiadania (Dz 9,1-19; 22,5-16; 26,9-18) samo za siebie świadczy, jak opowiadany fakt jest ważny dla narratora. Tutaj, być może bardziej niż w listach, uwidacznia się starotestamentalny model powołania prorockiego. Oczywiście, że Paulusbild w Dziejach Apostolskich został skonstruowany przez Łukasza ze względu na przyjęte cele. Ważną kwestią, podnoszoną przez uczonych i już przez nas akcentowaną, jest problem, czy zmianę u Pawła należy oceniać bardziej w kategoriach nawrócenia, czy też wezwania. Problem ten został już odpowiednio naświetlony, a wnioski - przynajmniej, gdy chodzi o główną linię rozumowania - przemawiają za tym drugim rozwiązaniem ${ }^{12}$. Należy tylko dodać, iż w przypadku Pawła nie chodzi o zmianę religii, nawet jeśli powszechnie łączymy ją z ideą nawrócenia. Trudno jednak nie zgodzić się z tymi, którzy utrzymują, iż ,jeśli używamy terminu nawrócenie dla określenia doświadczenia Pawła, powinniśmy używać tego terminu także w odniesieniu do proroków: Jeremiasza i Izajasza. Tymczasem nie mówimy o ich nawróceniu, lecz o ich powołaniu; także doświadczenie Pawła jest pewnym wezwaniem do specyficznego powołania, do bycia wybranym przez Boga jako apostoł pogan. Misja ta jest celem. Stoimy wobec wezwania do misji, a nie wobec nawrócenia"13. Tym niemniej, jeśli redukuje się chrystofanię spod Damaszku do powołania prorockiego, akcent w sposób nieunikniony pada na otrzymane zadanie, a nie na osobiste doświadczenie egzystencjalnej zmiany: w konkluzji podkreśla się, że Paweł pozostaje Żydem, któremu została jedynie powierzona misja rozciągnięcia na narody podstawowych wartości Izraela; tak więc, różnica pomiędzy stadium poprzedzającym i stadium następującym po wezwaniu byłaby zależna wyłącznie od nowego pojmowania Prawa i pozostawałaby niezmienna. W każdym bądź razie, „fakt, że chodzi o obydwie rzeczy-

${ }^{11}$ Poza komentarzami por. G. Lohfink, La conversione di San Paolo, SB 4, Paideia, Brescia 1969; C. W. Hedrick, Paul's Conversion/Call. A Comparative Analysis of the three Reports in Acts, "Journals of Biblical Literature" 100 (1981), s. 415-432.

${ }_{12}$ Por. G. Pani, Vocazione di Paolo, o conversione?, w: L. Padovese (red.), Paolo di Tarso. Archeologia - storia - ricezione, Cantalupa (TO) 2009, s. 47-69; tenże, Conversione di Paolo o vocazione? La documentazione della Lettera ai Romani, w: tamże, s. 71-90.

${ }^{13}$ K. Stendahl, Paolo tra ebrei e pagani e altri saggi, Claudiana, Torino 1995, s. 59 (por. 55-76: „Powołanie, a nie wezwanie”). 
wistości: nawrócenie $\mathrm{w}$ sensie chrześcijańskim jest zawsze jednocześnie pewnym wezwaniem. Prawdą jest, że Paweł nie odnajduje nowego Boga do adoracji; on podkreślałby, że Bóg czczony przez niego jako chrześcijanina jest tym samym Bogiem, którego czcił jako wyznawca judaizmu: Bogiem Abrahama, Izaaka, Jakuba. Tym niemniej Pan, do którego on się zwraca i który do niego się zwraca, to Jezus; Jezus, który determinuje także jego myślenie o Bogu. Niezależnie od tego, co w judaizmie - jako takim - sądzi się o Bogu, Bóg był dla Pawła Tym, z którym można mnóstwo zyskać (por. Flp 3,7), i to poprzez posłuszeństwo prawu. Zyski te Paweł teraz uważa za straty... Była to radykalna zmiana $\mathrm{w}$ orientacji religijnej, której towarzyszyła równie radykalna zmiana $\mathrm{w}$ działaniu: aktywny prześladowca staje się głosicielem i ewangelizatorem jeszcze bardziej dynamicznym. Jeśli te radykalne zmiany nie są podyktowane nawróceniem, trudno jest zrozumieć, czym byłoby owo nawrócenie. To wszystko jednak nie musi prowadzić do eliminacji lub niedowartościowania elementu powołania"14.

Istnieje ryzyko, że w kwestii tego typu "czyni się dwa kroki do przodu i krok do tyłu". Moim zdaniem, antynomii tej nie można rozwiązać w sposób jednoznaczny. Jeśli termin „nawrócenie” rozumie się w ścisłym sensie właściwym religiologii, wydaje się on ewidentnie niewłaściwy, aby określić nim przypadek apostoła Pawła, który rezygnuje jedynie z bezwzględnej wartości Tory i Świątyni, charakteryzującej wyjściowy stan jego religijności, ale nie rezygnuje $\mathrm{z}$ monoteizmu, $\mathrm{z}$ idei ludu Bożego, z Pisma, z wyborów moralnych, z podstawowych kategorii religijnych. Jeśli natomiast przyzna się temu terminowi znaczenie szersze przynajmniej w odniesieniu do prawdziwego i właściwego „przetasowania kart”, zarówno typu hermeneutyczno-teologicznego wynikające z decyzyjności Jezusa Chrystusa, jak i odnoszące się do tożsamości osobowej polegającej na zupełnie nowym życiowym zaangażowaniu, wówczas nie można nie odwołać się do owego znaczenia, zważywszy przy tym, że u żadnego ze starożytnych proroków nigdy nic podobnego się nie zweryfikowało.

Reasumując, przypadek Pawła jest jedyny w całej optyce biblijnej. Jawi się on również - w pewnym sensie - jako przypadek paradygmatyczny. Widać jasno na jego przykładzie, że jeżeli jest prawdą, iż nawrócenie nie może istnieć bez powołania $\mathrm{u}$ swoich podstaw, prawdą jest także to, że powołanie powoduje istotną przemianę życia. Aby się o tym

${ }^{14}$ C. K. Barrett, The Acts of the Apostles, Edinburgh 1994, s. 442. 
przekonać, wystarczy dobrze zdefiniowana typologia, choć z pewnością jest to typologia złożona.

\section{NAWRÓCENIE I WIARA}

Bezpośrednia relacja pomiędzy dwiema koncepcjami być może nie jest łatwa gdzie indziej do odnalezienia z taką jasnością, jak w słowach samego Jezusa zawartych w Mk 1,15: „Nawracajcie się (metanoeîte = transmentamini) i wierzcie w Ewangelię". Między różnymi nowotestamentalnymi konstrukcjami słowa „wierzyć”, jest to jedyny przypadek, w którym jest ono skonstruowane z przyimkiem położenia w miejscu „, $\mathrm{w}^{\prime \prime 15}$.

Na tle tego sformułowania można dostrzec jego użycie, które występuje w Biblii greckiej, zwanej Septuagintą, w sześciu różnych przypadkach, gdzie zresztą wiernie przekazuje oryginalną konstrukcję hebrajską/ aramejską. Widać to już na poziomie świeckim w trzech fragmentach: 1 Sm 27,12 („Akisz wierzył w Dawida / liczył na Dawida”), Syr 32,21 („Nie wierz / nie ufaj w drogę/drodze bez przeszkód”), i Jr 12,6 („Nie wierz / nie ufaj im"). Lecz w sposób wyjątkowy znacząca jest konstrukcja na poziomie teologicznym w trzech innych fragmentach: Ps 77/78,22 („Nie uwierzyli w Boga”), Ps 105/106,12 („W słowa więc Jego uwierzyli”) oraz Dn 6,23/24 (,Zawierzył w swojego Boga” / tłum. polskie: "Zaufał swemu Bogu'). We wszystkich tych przypadkach konstrukcja semicka 'āman $b^{e}$ dobrze wyraża pierwotny sens terminu ${ }^{16}$, który implikuje ideę bezpieczeństwa/stabilizacji, i oznacza dosłownie „polegać na / opierać się na”, a zatem "zawierzyć się komuś, uważać za godnego zaufania”; ten sam odcień znaczeniowy jest zachowywany w interpretacji tekstu greckiego. Stąd zdanie z Ewangelii Mk 1,15 przedstawia zaproszenie, nie tyle do przylgnięcia intelektualnego do jakiegoś oświadczenia dok-

15 Trzeba przywołać tutaj dwa inne teksty, które pozornie reprezentują tę samą syntagmę, tzn. J 3,14-15 („potrzeba, aby wywyższono Syna Człowieczego, aby każdy, kto w Niego wierzy, miał życie wieczne”) oraz Ef 1,13 („W Nim [Chrystusie] także i wy usłyszeliście słowo prawdy, Dobrą Nowinę o waszym zbawieniu. W Nim również uwierzyliście i zostaliście naznaczeni pieczęcią Ducha Świętego, który był obiecany"); zob. komentarze.

${ }^{16}$ Weźmy pod uwagę, że rzeczownik hebrajski ‘ěmûnāh (pochodzący od czasownika 'āman i przetłumaczony w LXX jako pístis), bardziej, niż „wiara”, dosłownie oznacza „stabilizacja, niewzruszoność, stałość, bezpieczeństwo” i jedynie w sensie pochodnym „prawdziwość, zdolność zawierzenia, zaufanie” (por. słowniki hebrajskie). 
trynalnego, ile do egzystencjalnego i trwałego zanurzenia się w Ewangelię, czyli polegania na niej / zakorzenienia się w niej / zakotwiczenia w niej, gdyż stanowi ona solidną glebę, na której można z zawierzeniem budować całe swoje życie.

W tym kontekście może być interesujące porównanie tekstu rabinackiego z tekstem Pawłowym dotyczącym odpuszczenia grzechów. W Tosefcie czytamy, że „ani ofiara (datek) za grzech, ani ofiara ekspiacyjna, ani śmierć, ani Kippûr (=post), nie mogą przynieść zadośćuczynienia (przebłagania), jeśli brak jest żalu/tešuvāh" (Jomà 5,9). Natomiast w Rz 3,25 czytamy w odniesieniu do Jezusa Chrystusa, że „Bóg otwarcie ustanowił [Go] narzędziem przebłagania, przez wiarę, mocą Jego krwi, dla odpuszczenia grzechów”. Widać tu jasno, że jakiemuś „dziełu”, czy to kulturowemu, czy moralnemu, przeciwstawia się wydarzenie, o które zatroszczył sam Bóg dzięki krwi Chrystusa, i z którym sprzęga się wiara człowieka wierzącego, wydobywającego na światło typowe extra nos zbawienia.

Paweł, ponadto, używa interesującej konstrukcji „od wiary ku wierze" (Rz 1,17: ek písteōs eis pístin). Historia egzegezy zna wiele różnych interpretacji tej syntagmy. Lecz, biorąc pod uwagę większość współczesnych komentatorów ${ }^{17}$, najlepiej jest widzieć w Pawłowej konstrukcji prosty wybieg retoryczny mający na celu maksymalną apoteozę faktu wiary. To jakby Apostoł chciał - co już sugerował w poprzednim wierszu 16 („Ewangelia jest mocą Bożą dla dobra każdego wierzącego”; tłum. polskie: „ku zbawieniu dla każdego wierzącego”) - powiedzieć z największym naciskiem, że wiara jest jedynym sposobem odnoszenia się do objawionej przez Boga zbawczej sprawiedliwości, obecnej w przekazie ewangelicznym, i że tylko wiara pozwala pojąć, iż w Ewangelii jest wprowadzone $\mathrm{w}$ czyn objawienie tego typu sprawiedliwości. Nie tylko Ewangelia i wiara, lecz również Boża sprawiedliwość (zbawcza) i wiara są doskonale jednolite. Oznacza to, że wiara nie jest jedynie warunkiem przylgnięcia do sprawiedliwości Bożej, lecz jest już samym przylgnięciem $^{18}$.

17 Por. analizę tekstu w: R. Penna, Lettera ai Romani, SOC 6, Bologna 2010, s. $75-82$.

${ }^{18}$ Por. Tomasz z Akwinu, Super epist. ad Rom. 4,5: „To nie jest tak, że dzięki wierze zasługuje się na sprawiedliwość, lecz sama wiara jest pierwszym aktem sprawiedliwości, którego Bóg w nas dokonuje. Rzeczywiście, poprzez sam fakt, iż ten, który ma być usprawiedliwiony, wierzy w Boga, człowiek poddaje się Jego usprawiedliwieniu 
Na potwierdzenie takiego sposobu postrzegania rzeczywistości, Apostoł przytacza cytat biblijny, pierwszy z całej serii zawartej w Liście do Rzymian: „Sprawiedliwy z wiary żyć będzie” (=Ha 2,4). Formuła zastosowana w celu wprowadzenia tego cytatu (,jak jest napisane") uwypukla wartość cytowanego tekstu jako argumentu: rzeczywiście, odwołanie się do Pisma Świętego konstytuuje argument ex auctoritate, zastosowany, aby potwierdzić zasadę, że wiary $\mathrm{w}$ procesie usprawiedliwienia nie da się niczym zastąpić. Fragment z Księgi Habakuka jest bardzo znaczący dla Pawła, zwłaszcza, że jest on jednym z nielicznych tekstów biblijnych cytowanych przez Apostoła więcej, niż jeden raz (występuje także w Ga 3,11); jego umieszczenie w Liście do Rzymian jeszcze bardziej podkreśla jego wartość jako tekstu podstawowego i - jeśli można tak rzec - tekstu programowego (wziąwszy pod uwagę również fakt, iż w cytacie z Ga 3,11 brakuje uroczystej formuły wprowadzającej, która tutaj jest obecna). Ciekawe jest, że tekst prorocki zaadaptowany przez Pawła nie ma takiej samej wagi, jak ten zarówno $\mathrm{z}$ hebrajskiego tekstu masoreckiego („sprawiedliwy ze względu na swoją wiarę będzie żył”), jak i z greckiej Septuaginty („sprawiedliwy ze względu na moją wierność będzie żył”) ${ }^{19}$. Niejednakowe potraktowanie tych tekstów nie powinno dziwić, zarówno dlatego, że starożytna praktyka pozwalała na adaptację przekładu jakiegoś tekstu dla potrzeb własnego wywodu, jak i dlatego, że zróżnicowane użycie tego samego tekstu z Ha 2,4 jest potwierdzone w innych źródłach: zarówno w Nowym Testamencie (por. Hbr 10,37-38: „mój sprawiedliwy będzie żył przez wiarę"), jak i w Talmudzie (por. b.Makkot 24a) ${ }^{20}$.

Należy również odnotować jeszcze jeden wariant w cytowaniu Ha 2,4, który dotyczy sensu przypisywanego terminowi „sprawiedliwy”. Podczas gdy w tekście starotestamentalnym chodzi o pojedynczego Żyda,

i w ten sposób osiąga cel". Analogicznie, w swoim słynnym komentarzu K. Barth powie, że „Ewangelia jest tylko wiarygodna... Ona jest zawiasem, a nie drzwiami” (L'Epistola ai Romani, Milano 1962 [oryg. niem. 1962], s. 11 i 14).

${ }^{19}$ Zob. dyskusję odnośnie do tych tekstów: R. Penna, Il giusto e la fede. Ab 2,4b e le sue antiche riletture giudaiche e cristiane, w: tenże, Vangelo e inculturazione, s. 484-511.

${ }^{20} \mathrm{~W}$ tym tekście z Talmudu babilońskiego dokonano wprost zredukowania 613 przykazań, przekazanych - według tradycji rabinackiej - Mojżeszowi przez Boga, do jednej reguły wiary, o której mówi właśnie Habakuk. Pomijając już fakt, że słowa proroka są traktowane na równi z przykazaniem, z tekstu Talmudu - jako rzecz nową - można wydobyć to, iż fragment Ha 2,4b nie tylko jest pojmowany jako kompendium wszystkich przykazań, ale nawet jako tekst przeciwstawiający się tym, którzy pragną szukać Boga, zachowując w pełni wszystkie 613 przykazań. 
lub co najwyżej o personifikację Narodu Wybranego, który poddaje się całkowicie Panu, aby ostać się - tak pojedyncza osoba, jak i naród - w obliczu zagrożenia zbrojnego najazdu, u Pawła chodzi o każdego człowieka, bez względu na religię czy kulturę (por. werset 16b: „najpierw dla Żyda, potem dla Greka"), z uwagi na życie w perspektywie wieczności (por. Rz 2,7; 5,21; 6,22), co bynajmniej nie wyklucza wymiaru ziemskiego, ale go ujmuje poprzez ogólne określenia osobistej pełni i owocności (por. Rz 6,4.10-11.13; 12,1; 14,7-8). Tę nową, nabytą sprawiedliwość Paweł łączy przede wszystkim z samą wiarą, a nie z działaniem wynikającym z Prawa (por. Rz 3,28) ${ }^{21}$.

\section{PODSUMOWANIE}

Jak niewielu innych, Paweł pozostawił nam osobiste opisy, w których odnajdujemy bezpośrednio odzwierciedlone, jego własne, subiektywne doświadczenie. Uprzedza on w tym nowoczesność Augustyna, i proponuje nam wprost, w pierwszej osobie, to, co może oznaczać konkretnie nawrócenie: zupełnie coś innego, niż uśmiercenie człowieczeństwa i najlepszych indywidualnych cech osoby; nawrócenie przynosi natomiast reorganizację dotyczącą nowego, osobistego początku, która polega na wkroczeniu w ludzkie życie Jezusa Chrystusa.

Na bazie tej sytuacji możemy poczynić kilka ustaleń. Pierwsze dotyczy stosunku zachodzącego pomiędzy metánoia (Luter przetłumaczyłby transmentatio) i wiarą. Stosunek ten - jak widzieliśmy - jest mocno sugerowany w Mk 1,15b, gdzie te dwie rzeczywistości występują ściśle jedna po drugiej. Zgodnie ze swoją naturą, metánoia poprzedza wiarę i jest jej przyczyną; z drugiej strony, wiara następuje po niej jako pozytywne ukoronowanie niezbędnego momentu zerwania. Pierwsza implikuje oderwanie się, druga - przylgnięcie; lecz już w pierwszą jest wpisane ukierunkowanie ku czemuś nowemu, a w drugiej obecny jest aspekt wyboru, który wyklucza inne możliwości. Obydwie rzeczywistości, choć bardzo bliskie, nie mogą być jednak identyfikowane ze sobą czy też mylone.

${ }^{21}$ Wymóg sola fide można traktować jako tradycyjny, mający udokumentowanie, najpierw u Lutra, u Orygenesa, Hilarego, Bazylego, Ambrozjastera, Jana Chryzostoma, Cyryla Aleksandryjskiego, Augustyna, Teodora z Mopswestii, Teodoreta z Cyru, Bernarda, Tomasza z Akwinu (zob. materiały cytowane w: R. Penna, Lettera ai Romani, s. 274). 
Drugie ustalenie odnosi się do etycznego elementu samej wiary. Jak już akcentowaliśmy, ani Jezus, ani Paweł z pewnością nie głoszą powrotu do Tory, ale też nie są jej radykalnymi krytykami. W każdym przypadku metánoia - nawet pojmowana jedynie jako przezwyciężenie religijnej ograniczoności, złączona ze status quo, i tym samym rozumiana jako otwartość i dyspozycyjność wobec eschatologicznego i chrystologicznego novum Królestwa Bożego - bezwzględnie powoduje decyzję moralną, za którą całą odpowiedzialność ponosi pojedynczy człowiek.

W pismach Pawła problematyka: skrucha-nawrócenie nie może wspólistnieć z tą dotyczącą wiary, która jest typowa dla myśli teologicznej Pawła i odpowiadającego jej słownictwa ${ }^{22}$. Rzeczywistości, jaką jest metánoia (po hebrajsku tešûvāh, „powrót”), Paweł nie przypisuje żadnej decydującej roli $\mathrm{w}$ procesie usprawiedliwienia przed Bogiem, ponieważ nie mogła ona nie być postrzegana przez niego - jako kogoś niezłomnego moralnie - na równi z jednym z owych "dziel”, które zostały odrzucone jako przesłanka warunkująca łaskę Bożą ${ }^{23}$. Według Pawła, jedynie wiara w Jezusa Chrystusa (i złączony z nią chrzest) może spowodować - w sposób determinujący - wprowadzenie człowieka w „sprawiedliwość", w odpuszczenie grzechów, w nowe przymierze, w świętość, $\mathrm{w}$ nowe stworzenie, itd. $\mathrm{Z}$ tego punktu widzenia jest możliwe, mutatis mutandis, przywołanie i przypisanie Pawłowej pístis tego wszystkiego, co międzytestamentalny judaizm mówi w celu egzaltacji metánoia/t šš̂vā $h^{24}$. Z pewnością można utrzymywać, że „podczas, gdy u Jezusa nawrócenie zawierało wiarę, u Pawła to metánoia mieści się w pístis"25. Trzeba jednak to doprecyzować. Samo słownictwo związane z żalem (skruchą) i nawróceniem nie jest już możliwe po wydarzeniach paschalnych (por. jego brak

${ }^{22}$ Przypomnijmy, że czasownik pisteúein/wierzyć i rzeczownik pístis/wiara występują statystycznie 127 razy w samych tylko autentycznych Listach Pawłowych (odpowiednio: 41 i 86 razy); koncepcja stanowi materię dogłębnej i szerokiej refleksji w tych fragmentach, które są decydujące w rekonstrukcji poglądów charakterystycznych dla Apostoła (na ten temat zob. hasło: L. Morris, 'Fede', w: G. F. Hawthorne, R. P. Martin, D. G. Reid, Dizionario di Paolo e delle sue lettere, Cinisello Balsamo 1999, s. 605-615.

${ }^{23}$ Rzeczywiście, w literaturze rabinackiej, gdzie wiara jest celebrowana jako godna rekompensaty (por. Mek.Ex. traktat Beshallah 7, 130-164), tešûvāh jest rozumiana jako dzieło zasługujące na nagrodę (Mishnà, P.Avôt 4, 11, i zaliczona do „dobrych dzieł").

${ }^{24}$ Zob. piękną definicję, którą Filon Aleksandryjski określa żal jako „młodszego brata doskonałej niewinności” (Somn. 1,91), gdyż „nigdy nie grzeszyć to rzecz właściwa Bogu, natomiast żałować to coś właściwego dla człowieka mądrego" (Fug. 157).

${ }^{25}$ J. Behm, w: Grande Lessico del Nuovo Testamento, VII, Brescia 1971, kol. 1185. 
w Ewangelii Jana) albo jest obecne w sposób mocno ograniczony (por. właśnie Pawła). Dla judaizmu implikuje to zasadniczo koncepcję skruchy, co narusza Torę, i nawrócenia, to znaczy „powrotu” przy pełnym zachowaniu Tory. Wszystko to oznacza powrót do tego, co było, do tradycyjnego schematu Przymierza Mojżeszowego. Ale czy powrót taki jest możliwy w obliczu nadzwyczajnego wydarzenia związanego z pewnym Nazarejczykiem, ukrzyżowanym ze względu na nasze grzechy? Tutaj nie chodzi o powrót do obrazu religijnych opowiadań, obrazu znanego, a następnie przełamanego przez grzesznika. Tutaj sam Bóg przełamuje stałe schematy (por. 1 Kor 1,19: „Wytracę mądrość mędrców...”), a przylgnąć do Niego oznacza uczynić krok do przodu: nie w stronę jakiegoś nowego wezwania legalnego, ale w stronę naprawdę ewangelicznej propozycji nieoczekiwanego i darmowego odkupienia, które obficie wypływa z przelanej na krzyżu krwi Chrystusa. Nie jest możliwe wyrażenie tej akceptacji za pomocą wąskiego słownictwa pochodzącego od metánoia i od $t^{e} \breve{s} u v a \bar{h} h$, które okazuje się zupełnie niewystarczające i nieodpowiednie. Jest to ewidentne w osobistym przypadku Pawła. Gdy Apostoł mówi o decydującym zwrocie $\mathrm{w}$ swoim życiu, mającym punkt kulminacyjny na drodze do Damaszku, nigdy nie posługuje się jednym z trzech terminów oznaczających nawrócenie (metánoeîn, metamelésthai, epistréfein). W jego przypadku nie chodzi o „nawrócenie” w ścisłym tego słowa znaczeniu, gdyż nie miał on podstaw, aby „żałować" - jako wyznawca judaizmu - z powodu swego życia, które nie było ani bałwochwalcze, ani niemoralne (por. Flp 3,6); istnieje więc ogromna różnica pomiędzy jego przypadkiem i przypadkiem Ateńczyka Polemona, który przechodzi od rozwiązłości do wstrzemięźliwości; jak również pomiędzy jego przypadkiem i królem Izatesem, który odstępuje od pogaństwa i przyjmuje judaizm. Odpowiednie terminy są inne i mocniejsze: objawienie (Ga 1,16), wezwanie/powołanie (Ga 1,15; Rz 1,1), łaska (1 Kor 15,10), oświecenie/olśnienie (2 Kor 4,6), poznanie o najwyższej wartości (Flp 3,8); te abstrakcyjne określenia stają się konkretne, gdyż zawsze odnoszą się do osobistego spotkania z Jezusem Chrystusem. Analogicznie rzecz ma się także w odniesieniu do każdego chrześcijanina, któremu Paweł przedstawia nieznane dotąd stwierdzenia dotyczące wiary i miłości (por. Rz 3,21-26; 8,31-39; Ga 5,6), pojednania (por. 2 Kor 5,20), przyjmowania daru (por. 2 Kor 6,1), radości dziękczynienia (por. 1 Kor 15,57), i nawet przemienienia (por. 2 Kor 3,18; Rz 12,2). Tym, co powoduje przebaczenie grzechów już nie jest żal zgodny z pisanym prawem, i jeszcze mniej żal rozumiany jako rezygnacja i wejście $\mathrm{w}$ samego siebie; jest nim natomiast 
„zmiana mentalności” możliwa jedynie dzięki spotkaniu z Ukrzyżowanym i Zmartwychwstałym, „który umiłował mnie i samego siebie wydał za mnie" (Ga 2,20). Taka metánoia już nazywa się wiarą! ${ }^{26}$

Co więcej, należy stwierdzić, że u podstaw Pawłowej powściągliwości znajduje się oryginalna koncepcja grzechu. Żal jest możliwy tam, gdzie pojawiła się osobista odpowiedzialność w popełnianiu grzechów, czyli tam, gdzie grzech polega po prostu na przekroczeniu Prawa. Tak więc, skrucha (połączona ewentualnie z rytualną ofiarą) powoduje odzyskanie sytuacji prawości. Paweł jednak głosi w tym względzie inną koncepcję. Podziela on jedynie częściowo tradycyjne pojmowanie grzechu jako przekroczenia jakiejś normy (por. 1 Kor 15,3; Rz 3,25). Jego stanowisko, zbieżne z pewnym nurtem apokaliptyki żydowskiej, jest odmienne: dla Pawła grzech istotowo jest faktem pre-moralnym (przed-moralnym), uosobioną mocą, która zniewala człowieka poza Chrystusem; lub lepiej: podstawową sytuacją, w którą człowiek jest radykalnie uwikłany nie licząc się z Jego wolą (por. Rz 5,12-21; 7,7-23)27. Z sytuacji tego typu nie wychodzi się $\mathrm{w}$ skrusze: nie jest ona potrzebna, aby przerwać niewolę, w której przebywaliśmy siłą. To, co należy uczynić, to całkowite zerwanie poprzez przejście z jednej sfery do drugiej, poprzez zamianę pana (który nami włada). To przejście dokonuje się dzięki czyjejś interwencji: dzięki śmierci Jezusa Chrystusa, z którą chrześcijanin odpowiednio się utożsamia nie poprzez skruchę (żal), ale poprzez uczestnictwo w samym wydarzeniu śmierci i zmartwychwstania (por. Rz 6,1-11; 2 Kor 5,14-15.17.21), nie tylko poprzez chrzest, ale przede wszystkim poprzez wiarę $\mathrm{w}$ akcie czystej łaski danej przez Boga ${ }^{28}$.

${ }^{26}$ Stusznie B. R. Gaventa, From Darkness to Light. Aspects of Conversion in the New Testament, Philadelphia 1986, s. 44, mówi o nowej „strukturze” myśli teologicznej Pawła, która przekracza konwencjonalne użycie słownictwa związanego z nawróceniem. Również S. Zedda, La conversione in S. Paolo, „Sacra Doctrina” 42 (1966), s. 195-210, który akcentuje to użycie (odwołując się najczęściej do dziejów Apostolskich jako źródła myśli Pawłowej), musi uznać, iż „pierwsze nawrócenie realizuje się, dzięki wierze, w chrzcie" (s. 204).

${ }^{27} \mathrm{Na}$ temat tej koncepcji Pawłowej zob. R. Penna, Origine e dimensione del peccato secondo Paolo: echi della tradizione enochica, w: tenże, Vangelo e inculturazione, s. 391-418.

${ }^{28}$ Tym, kto w ostatnich latach - bardziej niż inni - wydobył na światło ten wymiar myśli Pawłowej był E. P. Sanders, Paolo e il giudaismo palestinese. Studio comparativo su modelli di religione, Paideia, Brescia 1986, zwłaszcza 621-649 oraz 681-688. 
Na tej podstawie kształtuje się i rozwija nauczanie moralne Pawła, który - poza generalnym upomnieniem, aby „nie brać wzoru z tego świata" (por. 12,2) - konstruktywnie koncentruje się na tematyce agàpe (miłości) jako jedynej mierze życia, która zawiera w sobie całe Prawo (por. Rz 13,8-10) i która jest zwykłą manifestacją wiary w działaniu (por. Ga 5,6).

Tłumaczenie z języka włoskiego - ks. Daniel Brzeziński

Streszczenie. Jak niewielu innych, Paweł pozostawił nam osobiste opisy, w których odnajdujemy bezpośrednio odzwierciedlone, jego własne, subiektywne doświadczenie. Z tej zasadniczej autorefleksji podaje, jak rzeczywiste nawrócenie powinno być rozumiane. W jego opinii konkretnie nawrócenie może oznaczać coś zupełnie innego niż uśmiercenie człowieczeństwa i najlepszych indywidualnych cech osoby; nawrócenie przynosi natomiast reorganizację dotyczącą nowego, osobistego początku, która polega na wkroczeniu w ludzkie życie Jezusa Chrystusa.

Zgodnie ze swoją naturą, metánoia poprzedza wiarę i jest jej przyczyną; $z$ drugiej strony, wiara następuje po niej jako pozytywne ukoronowanie niezbędnego momentu zerwania. Pierwsza implikuje oderwanie się, druga - przylgnięcie; lecz już w pierwszą jest wpisane ukierunkowanie ku czemuś nowemu, a w drugiej obecny jest aspekt wyboru, który wyklucza inne możliwości. Obydwie rzeczywistości, choć bardzo bliskie, nie mogą być jednak identyfikowane ze sobą, czy też mylone. W każdym przypadku metánoia - nawet pojmowana jedynie jako przezwyciężenie religijnej ograniczoności, złączona ze status quo, i tym samym rozumiana jako otwartość i dyspozycyjność wobec eschatologicznego i chrystologicznego novum Królestwa Bożego - bezwzględnie powoduje decyzję moralną, za którą całą odpowiedzialność ponosi pojedynczy człowiek. Według Pawła, jedynie wiara w Jezusa Chrystusa moż wprowadzić człowieka w „sprawiedliwość”, w odpuszczenie grzechów, w nowe przymierze, w świętość, i w nowe stworzenie. Przebaczenie grzechów wyzwala w nas głęboką zmianę, która jest możliwa jedynie dzięki spotkaniu z Ukrzyżowanym i Zmartwychwstałym, "który umiłował mnie i samego siebie wydał za mnie" (Ga 2,20). Taka metánoia już nazywa się wiarą.

Słowa kluczowe: wiara; nawrócenie; metanowa; św. Paweł; grzech.

Abstract. Faith and conversion in St. Paul's life and thought. Like few others, Paul leaves us with personal details of his life of faith on which he has reflected and pondered. From this intense self-reflection he directly states how real conversion is to be understood. In his opinion, it is not something that needs to negate our common humanity nor is it the result of our best human efforts to attain it. True conversion comes from a desire for an absolute new beginning when Jesus Christ enters into our human life. 
Accordingly, this metánoia (as we have come to know it) both precedes faith and is the foundation of it. The life of faith itself is also the fruit of this radical change. Both metanoia and faith are closely related to one another, but care must be taken not to confuse them or think they are the same thing.

Metánoia can always be understood in this way, as an openness and availability to the eschatological and Christological novum of the Kingdom of God and, as such, in an absolute terms leads to a moral decision which an individual takes. According to Paul therefore, only faith in Jesus Christ may cause man to enter the reality of "justice", remission of sins, the New Covenant, sanctity, and the New Creation.

The remission of sins summons from us a profound change that is only possible in this encounter with the crucified and risen one, "who loved me and gave himself for me" (Gal 2:20). Such a metánoia is called faith.

Keywords: faith; conversion; metanoia; St. Paul; sin. 